\title{
Shingles, CTCAE
}

National Cancer Institute

\section{Source}

National Cancer Institute. Shingles, CT CAE. NCI Thesaurus. Code C143213.

A disorder characterized by the reactivation of herpes zoster virus. 